\title{
Characterization of Four University Hospitals Wastewater in Cotonou, Benin
}

\author{
Ghislain Emmanuel Sopoh ${ }^{1 *}$, Cyriaque Degbey ${ }^{1,2}$, Judicaël Todedji1 ${ }^{1}$, Fidèle Suanon ${ }^{3}$, \\ Arouna Yessoufou ${ }^{3}$, Justin Somadje ${ }^{3}$, Ferdinand Goudjo ${ }^{4}$, Jean Wilfried Hounfodji ${ }^{5}$, \\ Daouda Mama ${ }^{3}$
}

\footnotetext{
${ }^{1}$ Regional Institute of Public Health, Department of Environmental Health, University of Abomey-Calavi, Ouidah, Benin ${ }^{2}$ University Clinic of Hospital Hygiene, National University Hospital Center Hubert Koutoukou Maga, Cotonou, Benin ${ }^{3}$ Laboratory of Applied Hydrology, University of Abomey-Calavi, Cotonou, Benin

${ }^{4}$ Laboratory of Inorganic Chemistry and Environment, Faculty of Science and Technology, University of Abomey-Calavi, Cotonou, Benin

${ }^{5}$ Laboratory of Theoretical Chemistry and Molecular Spectroscopy, Faculty of Science and Technology, University of Abomey-Calavi, Cotonou, Benin

Email: `ghislainsop@yahoo.fr, comlancy@yahoo.fr, dosjudi@yahoo.fr, fidele.suanon@fast.uac.bj, arouna.yessoufou@gmail.com, okambawa91@gmail.com, fersedid@gmail.com, jeanhounfodji97@gmail.com,mkdaouda@yahoo.fr
}

How to cite this paper: Sopoh, G.E., Degbey, C., Todedji, J., Suanon, F., Yessoufou, A., Somadje, J., Goudjo, F., Hounfodji, J.W. and Mama, D. (2021) Characterization of Four University Hospitals Wastewater in Cotonou, Benin. Open Journal of Epidemiology, 11, 402-419.

https://doi.org/10.4236/ojepi.2021.114033

Received: August 23, 2021

Accepted: November 5, 2021

Published: November 8, 2021

Copyright () 2021 by author(s) and Scientific Research Publishing Inc. This work is licensed under the Creative Commons Attribution International License (CC BY 4.0).

http://creativecommons.org/licenses/by/4.0/

Open Access

\begin{abstract}
Introduction: Because of the specificity of their care activities, hospital wastewater contains various contaminants such as germs, disinfectants, metals, pharmaceuticals and chemical reagents, potentially infectious or toxic, which can be harmful to living organisms, or create ecological damage. This study aimed to analyze the quality of wastewaters produced by university hospitals of Cotonou in Benin. Methods: We conduct an analytical cross-sectional study including 30 wastewater samples from selected hospitals. An analysis of variance was performed at the significance level of 0.05. Results: Microbiological analysis showed the presence of germs such as total coliform types, faecal coliforms, fecal streptococcus, staphylococcus, yeasts and Clostridium perfringens in hospital wastewater samples. There was a significant difference $(p<0.05)$ in the microbial loads of various germs, except staphylococcus, between hospitals. With regard to the physicochemical parameters, only the conductivity complied with the standards for the discharge of wastewater into the environment. A significant difference was noted between hospitals, for the electrical conductivity of wastewater $(\mathrm{p}<0.05)$. The average levels of metals detected in the wastewaters were in line with Benin's standards. There was no difference between the average concentrations of metals except for copper $(\mathrm{p}<0.05)$. Conclusion: The wastewater produced by the university hospitals of Cotonou is of poor quality and therefore requires adequate prior treatment before discharge into the environment.
\end{abstract}




\section{Keywords}

Germs, Physicochemical Contaminants, Hospital Wastewater, Risks, Benin

\section{Introduction}

Water is essential for the hygiene and functioning of hospitals [1]. The wastewater discharged by hospitals presents health and environmental risks because of the nature and the importance of the substances they contain [2]. Thus, hospital managers must keep great interest in a better treatment and management of wastewater. The management of hospital wastewater is a real problem in developing countries, due to the inexistence of wastewater treatment and purification stations [3]. This hospital wastewater is continuously discharged into natural receptacles such as the ocean and lake, despite the ecotoxicity of 5 to 15 times greater than urban's [4]. Despite the ignorance of the quality of the wastewater produced by hospitals in Benin, they are continually discharged into Lake Nokoué and sea. It is of utmost importance to know the current quality of the wastewater discharged into environments [5].

Wastewaters from hospitals contain potentially pathogenic micropollutants. The presence of substances in the environment is considered an emerging subject due to uncertainties related to the risk that they represent for terrestrial and aquatic ecosystems [6] [7]. Despite the health and environmental risks of hospital wastewater, there are almost no regulations on their treatment before discharge into the environment. The World Health Organization (WHO) document "safe management of healthcare waste" [8] is the only existing directive concerning hospital wastewater. In Benin, there is no specific directive concerning the management of hospital wastewater, but decree $\mathrm{n}^{\circ}$ 2001-109 of April 4, 2001 defines the standards quality for wastewater applications in the country and the procedures for discharging wastewater [9].

The rejection of hospital wastewater in the environment without prior treatment has become a subject of global concern in the fields of the environment and public health and arouses the interest of scientists and public authorities. In recent decades, the scientific community has focused on the biological, physical and chemical characteristics of hospital wastewater in order to assess the potential risks associated with their discharges into aquatic environments. Pollutants such as total and fecal coliforms, chemical residues (detergents), pathogens (Escherichia coli, Staphylococcus aureus, Pseudomonas aeruginosa, Salmonella and Vibrio) and potentially toxic metals (cadmium, copper, cyanide, iron, gadolinium, nickel, lead, platinum, zinc, phenol, etc.) have been quantified in hospital wastewater. The chronic exposure of aquatic organisms to these substances explains the emergence of various phenomena such as hormonal imbalances, resistance to antibiotics and all other harmful impacts on the environment [8] [10]. 
The discharge of untreated hospital wastewater into the surface waters in Benin poses ecotoxicological risks and threatens public health since the pollutants from these wastewaters can enter the food chain through consumed fish products [5]. It, therefore, becomes important to know the quality of the wastewater produced in university hospitals which are the greatest producers of hospital wastewater. Hence, this study aimed to assess the microbiological, physicochemical and toxicological quality of the wastewater from university hospitals in Cotonou.

\section{Material and Methods}

\subsection{Study Sites}

The study was conducted in four of the six university hospitals of the city of Cotonou, in the Littoral department of Benin: the National University Hospital " $\mathrm{Hu}$ bert Koutoukou MAGA" (CNHU-HKM), the University Hospital "de la Mere et de l'enfant" (CHU-MEL), the Army Instruction University Hospital of Cotonou (HIA-CHU); and the District University Hospital of Suru Léré (CHUZSL). The university hospitals are national referral centers in the health system, and training setting for health professionals. These four centres were chosen because of the diversity of disciplines, and the medical and technical services available as well as because of the variety of pathologies treated there, at contrary to the other two centres which, rather, are specialized.

The CNHU-HKM is the most important health establishment in Benin. It offers referral care in several surgical and medical specialties, and various diagnostic exploration specialties. It has a competent medical team. The CNHU-HKM has an activated sludge wastewater treatment station with a capacity of $6000 \mathrm{~m}^{3}$, with an initial design flow of $350 \mathrm{~m}^{3}$ day, which unfortunately is no longer functional.

The CHU-MEL is a referral hospital in the fields of pediatrics and gynecology-obstetrics. It includes neonatal, pediatric, pediatric surgery, gynecology and obstetrics, as well as diagnostic exploration services (biology, radiology). The CHU-MEL has a wastewater treatment station and uses the septic tank system. The treatment station receives part of the wastewater produced by the various services.

The CHUZ-SL's mission is to meet the health needs of the populations of its coverage area and elsewhere. It includes emergency departments, pediatrics, general medicine, surgery, maternity, ophthalmology, physiotherapy and diagnostic exploration services.

The HIA-CHU of Cotonou is under the supervision of the Directorate of Army Health Services (DSSA) attached to the Ministry of Defense. It is also a referral hospital in Cotonou.

The CHUZ-SL and the HIA-CHU do not have a treatment station. Wastewater and sewage are drained to septic tanks, designed to collect, settle and digest, by anaerobic fermentation, organic matter contained therein. Septic tanks, gen- 
erally made up of three compartments, are made of concrete, inserted into the ground.

\subsection{Study Type}

This is an analytical cross-sectional study involving 30 samples from hospital wastewater treatment station and septic tanks.

\subsection{Sampling Method and Technique}

The health services whose septic tanks were sampled were selected using a reasoned and non-probabilistic technique. The wastewater collected were that of health services at high risk of infection. The 30 hospital wastewater samples were collected from the four hospitals included in the study. The number of samples in each hospital was proportional to the number of septic tanks receiving wastewater from the health services.

\subsection{Collection and Transport of Samples}

The samples were collected in $500 \mathrm{~mL}$ pre-sterilized glass bottles for microbiological analysis and in $1.5 \mathrm{~L}$ plastic bottles for physico-chemical and toxicological analyses. Before being filled, on-site, the bottles were washed three times with the wastewater to be collected. They were then filled to the brim and then closed with a screw cap to avoid any gas exchange with the atmosphere. They were transported in coolers fitted with frozen accumulators at a temperature between $2^{\circ} \mathrm{C}$ and $8^{\circ} \mathrm{C}$ to keep the samples cool, preserve them from light, and thus, prevent them from undergoing biological, physical or even chemical transformations. The analyses were carried out within 48 hours after the sampling.

\subsection{Data Processing and Analysis}

The laboratory analyzes were carried out at the Public Health Research and Expertise Laboratory of Hospital Hygiene service of the CNHU-HKM.

\subsubsection{Microbiological Analysis}

The microbiological analysis aimed to identify and enumerate the total coliforms, fecal coliforms, fecal streptococcus, staphylococcus, yeasts and clostridium. The analyses were proceeded by the membrane filtration method. These microorganisms were identified and counted by filtering $100 \mathrm{~mL}$ of the samples on a 0.45 $\mu \mathrm{m}$ in diameter pores membrane. The membranes were then placed on selective media for a defined temperature and time $\left(37^{\circ} \mathrm{C}\right.$ and $44^{\circ} \mathrm{C}$ for 24 hours to 48 hours in a thermostated controlled oven immediately after filtration) depending on the type of germs sought. The specific agar media used for the enumeration of coliforms are Eosin Methylene Blue (EMB), bile esculin azide agar (BEA) for fecal streptococcus, chapman medium for staphylococcus; Tryptone Sulfite Neomycin (TSN) medium for Clostridium perfringens. Mushrooms and yeasts were searched by culture on sabouraud + chloramphenicol. The dishes were incubated at $25^{\circ} \mathrm{C}$ or at room temperature for 3 to 7 days. 
Additional tests were done to determine the type of bacteria. The API 20E gallery was used for coliforms and gram-negative bacilli isolated on EMB while the DNase tests, catalase, coagulase were carried out for cocci isolated on Chapman medium.

\subsubsection{Physico-Chemical Analysis}

The global pollution parameters were used to determine the physico-chemical quality of hospital wastewater: electrical conductivity, turbidity, biochemical oxygen demand after 5 days $\left(\mathrm{BOD}_{5}\right)$, chemical oxygen demand (COD), suspended matter (SM), dissolved oxygen, total ammonium and phosphorus. They were analyzed according to the protocols recommended by Rodier et al. (2009) [11]. Electrical conductivity, dissolved oxygen and turbidity were determined in situ using a Multi 3320 WTW system. BOD $_{5}$ was determined by the dilution and seeding method with the addition of allyl-thiourea according to standard NF EN 1899-1. The COD was determined according to the protocol described by standard NF T90-101. The assay was carried out by the potassium dichromate method. The suspended matter (SM) was determined by filtration through a fiberglass filter. The total ammonium and phosphorus were determined by the ascorbic acid method (Spectrophotometric method).

\subsubsection{Toxicological Analysis: Analysis of Metals}

The analysis of heavy metals consisted in finding in the wastewater the following elements: Lead $(\mathrm{Pb})$, Cadmium (Cd), Iron ( $\mathrm{Fe})$, Copper $(\mathrm{Cu})$, Zinc ( $\mathrm{Zn})$, Manganese (Mn), Arsenic (Ar), Total Chromium (Cr), Hexavalent Chromium (CHV), Nickel (Ni) and Colbat (CO). Heavy metals were analysed using a flame atomic absorption spectrophotometer, by Dithizone spectrometric method, after mineralization of the samples.

\subsection{Data Analysis}

The results of the laboratory analyze were processed using a combination of statistical methods. A first statistical approach was based on a simplified analysis of the results of studied parameters (calculation of the average concentrations) in comparison with the standards of the WHO (2014) [12] and those of Benin [9]. A second approach was based on the analysis of variance with a factor (ANOVA) for each parameter. The mean comparison graphs with their $95 \%$ confidence interval $(95 \%$ CI) were produced. This test was followed by the Bonferroni test to determine the significant differences between pairs of University Hospitals. The significance level used is $\alpha=0.05$. The various statistical analyzes were carried out with SPSS version 21 software.

\section{Results}

\subsection{Microbiological Characterization}

The results of microbiological analyzes of University Hospital's wastewater in Cotonou are shown in Table 1 and Figure 1. 
Table 1. Average microbial loads $(\mathrm{CFU} / 100 \mathrm{~mL})$ of university hospital's wastewater in Cotonou, compared to the WHO standards.

\begin{tabular}{ccccccc}
\hline Variable & NE & Min & Max & Average & $\begin{array}{r}\text { Standard } \\
\text { deviation }\end{array}$ & $\begin{array}{c}\text { WHO } \\
\text { standards }\end{array}$ \\
\hline $\mathrm{TC}^{*}\left(10^{5}\right)$ & 30 & 0.8 & 17.30 & 4.32 & 4.04 & LS \\
$\mathrm{FC}^{\star}\left(10^{5}\right)$ & 30 & 0.11 & 3.81 & 0.59 & 0.84 & $2 \times 10^{3}$ \\
$\mathrm{FS}^{*}\left(10^{5}\right)$ & 30 & 0 & 28.00 & 4.32 & 5.61 & LS \\
Sta $\left(10^{5}\right)$ & 30 & 0 & 6.24 & 1.31 & 1.74 & LS \\
Clos $^{*}\left(10^{5}\right)$ & 30 & 0 & 0.20 & 0.05 & 0.058 & LS \\
yeasts ${ }^{*}\left(10^{5}\right)$ & 30 & 0 & 61.00 & 5.63 & 14.03 & LS \\
\hline
\end{tabular}

${ }^{\star}$ Significant difference; NE: Number of sample; Min: Minimum value; Max: Maximum value; TC: Total coliforms; FC: Fecal coliforms; FS: Fecal streptococcus; Sta: Staphylococcus; Clos: Clostridium; LS: Lack of standard; CFU: Colony forming unit.

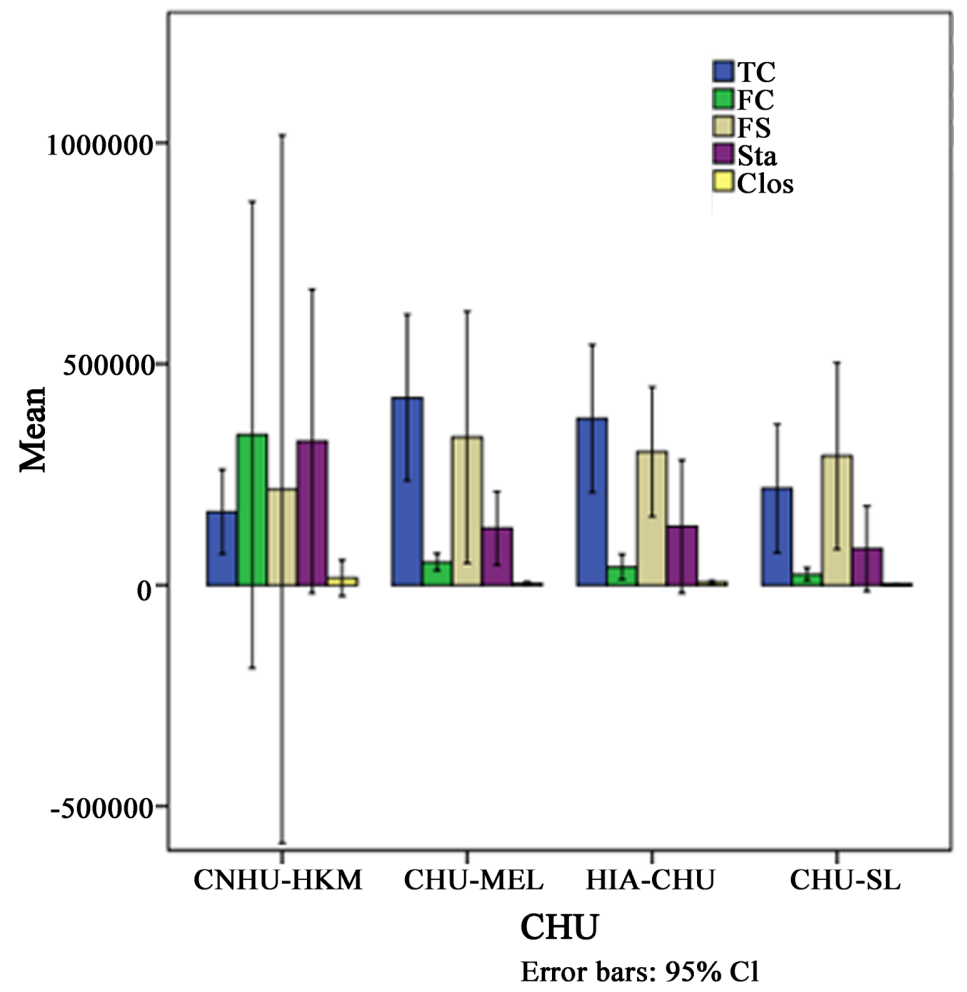

TC: Total coliforms; FC: Fecal coliforms; FS: Fecal streptococcus; Sta: Staphylococcus; Clos: Clostridium.

Figure 1. Comparison of average concentrations of microbial loads per UHC.

Total and fecal coliforms were highlighted in all the samples taken. Total coliform concentrations range from $0.8 \times 10^{5} \mathrm{CFU} / 100 \mathrm{~mL}$ to $17.3 \times 10^{5} \mathrm{CFU} / 100 \mathrm{~mL}$ with an average of $4.32 \times 10^{5} \mathrm{CFU} / 100 \mathrm{~mL}$. The concentrations of fecal streptococcus vary from $0 \mathrm{CFU} / 100 \mathrm{~mL}$ to $28 \times 10^{5} \mathrm{CFU} / 100 \mathrm{~mL}$ with an average of 4.32 $\times 10^{5} \mathrm{CFU} / 100 \mathrm{~mL}$. Fecal coliforms are less abundant in the wastewater analyzed. Their concentrations varied from $0.11 \times 10^{5}$ to $3.81 \times 10^{5} \mathrm{CFU} / 100 \mathrm{~mL}$ with an 
average of $0.59 \times 10^{5} \mathrm{CFU} / 100 \mathrm{~mL}$. Microbial loads varied significantly between hospitals ( $\mathrm{p}<0.05)$ except for staphylococcus, which was found to be insignificant $(\mathrm{p}>0.05)$.

Microbiological analyses showed the presence of germs of total coliform types, fecal coliforms, fecal streptococcus, staphylococcus, yeasts and Clostridium perfringens in hospital wastewater.

The average concentrations of staphylococcus obtained at CNHU-HKM were higher than those obtained in the other three centers (CHU-MEL, HIA-CHU, CHUZ-SL). The hospital wastewater of the CHU-MEL had a higher average microbial load of fecal streptococcus than those of the other $\mathrm{CHU}$ with a significant difference between the microbial loads of the CHU-MEL and HIA-CHU on the one hand and between those of the CHU-MEL and the CHUZ-SL on the other hand ( $\mathrm{p}<0.05)$. The microbial loads of fecal coliforms varied significantly between the CNHU-HKM and the three other hospitals $(\mathrm{p}<0.05)$.

\subsection{Physico-Chemical Characterization}

The average concentrations of the physicochemical parameters of the four CHUs are presented in Table 2.

The results of analyzes were compared to the WHO standard and those adopted in Benin. Apart from the conductivity and the dissolved oxygen, all the other parameters values were higher than the standards defined for wastewater to be discharge in the environment. The average of EC is significantly lower than the standards, when the DO average is above the standards, even not significantly different from the standards.

Table 2. Results of physico-chemical analyzes of wastewater $\left(\mathrm{mg} \cdot \mathrm{L}^{-1}\right)$ of university hospital wastewater in Cotonou, compared to the WHO and Benin standards.

\begin{tabular}{ccccccc}
\hline Variable & NE & Min & Max & Average & $\begin{array}{c}\text { Standard } \\
\text { deviation }\end{array}$ & $\begin{array}{c}\text { WHO and } \\
\text { Bénin } \\
\text { standard }\end{array}$ \\
\hline EC & 30 & 295.0 & 3210 & 1310.33 & 918.60 & $<2000$ \\
Turbidity & 30 & 4.90 & 198.1 & 74.14 & 57.20 & $<5$ \\
SM & 30 & 9.00 & 264 & 98.83 & 73.0 & $35^{\mathrm{a}}$ \\
DO & 30 & 0.24 & 4.20 & 1.43 & 1.30 & $>5$ \\
BDO 5 & 30 & 1.97 & 470.00 & 98.14 & 132.31 & $<25^{\star}$ \\
COD & 30 & 5.33 & 874.20 & 181.14 & 251.12 & $<125^{\star}$ \\
Am & 30 & 0.10 & 494.52 & 66.63 & 123.22 & $<0.2$ \\
TP & 30 & 5.00 & 300.0 & 42.32 & 62.16 & $<10$ \\
\hline
\end{tabular}

${ }^{\star}$ Significant difference; ${ }^{a}$ Benin standard only; NE: Number of samples, Min: Minimum value; Max: Maximum value; EC: Electrical conductivity; SM: Suspended matter; BOD $_{5}$ : Biochemical oxygen demand; COD: Chemical oxygen demand; DO: Dissolved oxygen; Am: Ammonium; TP: Total phosphorous. 
A significant difference was noted between the hospitals, for the electrical conductivity $(p<0.05)$. No significant difference $(p>0.05)$ was observed between the other global pollution parameters (Figure 2).

The results showed that hospital wastewater from CHUs were moderately mineralized and had very high organic pollution. The EC of the wastewater varies between $295 \mu \mathrm{S} / \mathrm{cm}$ and $3210 \mu \mathrm{S} / \mathrm{cm}$, with an average of $1310.33 \pm 918.60$ $\mu \mathrm{S} / \mathrm{cm}$. The wastewater had high levels of nutritive salts, including nitrogenous compounds, with contents of $0.102 \mathrm{mg} / \mathrm{L}$ to $494.52 \mathrm{mg} / \mathrm{L}$ and an average of 66.63 $\mathrm{mg} / \mathrm{L}$ for Am (Figure 2).

The average EC $(2361.63 \mu \mathrm{S} / \mathrm{cm})$ of the CHUZ-SL wastewater was higher than that of the three other Hospitals with a significant difference $(p<0.05)$ between the values obtained at the CHU-MEL and those of the HIA-CHU. The EC values of CNHU-HKM, CHU-MEL and HIA-CHU were $974.50 \mu \mathrm{S} / \mathrm{cm}, 743.63 \mu \mathrm{S} / \mathrm{cm}$ and $1018.17 \mu \mathrm{S} / \mathrm{cm}$, respectively. The wastewater of the CNHU-HKM presented higher values of turbidity, $\mathrm{BOD}_{5}$, and $\mathrm{COD}$ followed by $\mathrm{HIA}\left(\mathrm{BOD}_{5}=135.31\right.$; $\mathrm{COD}$ $=256.33$ ) which indicates an important organic pollution compared to the other centers, but with no significant difference ( $p>0.05)$.

The wastewater of HIA-CHU and CHUZ-SL had a slightly high MES, Am and TP values compared to the other two CHUs but with no significant difference

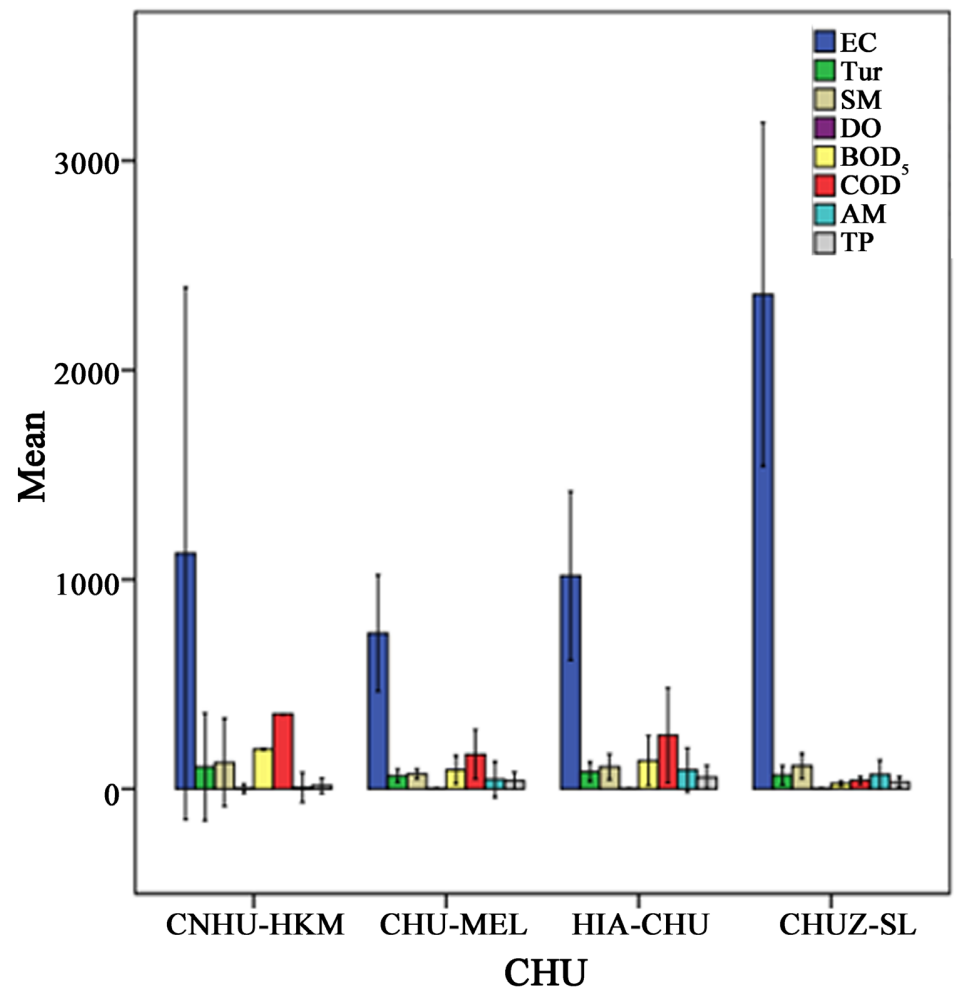

Error bars: 95\% Cl

EC: Electrical conductivity; SM: Suspended matter; BOD $:$ Biochemical oxygen demand; COD: Chemical oxygen demand; DO: Dissolved oxygen; TP: Total phosphorous.

Figure 2. Comparison of average concentrations of physico-chemical parameters by CHU. 
$(\mathrm{p}>0.05)$

\subsection{Toxicological Characterization}

The average heavy metal concentrations of the four CHUs are presented in $\mathrm{Ta}$ ble 3 .

The average concentrations of the heavy metals observed in the wastewater were in conformity with the Benin standards for the discharge of wastewater into the environment.

The wastewater of the CHUs had globally a high concentration of copper. However, the one of the CNHU-HKM $(2.76 \mathrm{mg} / \mathrm{L})$ seems higher than that of the three other centers $(1.89 \mathrm{mg} / \mathrm{L}$ at the CHU-MEL; $2.10 \mathrm{mg} / \mathrm{L}$ at the HIA-CHU, 1 , $62 \mathrm{mg} / \mathrm{L}$ at CHUZ-SL), but without a significant difference $(p>0.05)$. The wastewater sampled at CHUZ-SL had a higher lead content $(0.24 \mathrm{mg} / \mathrm{L})$ than that of CNHU-HKM (0.17 mg/L), HIA-CHU (0.18 mg/L) and CHU-MEL $(0.22 \mathrm{mg} / \mathrm{L})$ but without significant difference ( $\mathrm{p}>0.05)$.

The average manganese concentrations in the CNHU-HKM wastewater were higher than those of the other CHUs and varied between $0.10 \mathrm{mg} / \mathrm{L}$ and 0.18 $\mathrm{mg} / \mathrm{L}$ with an average of $0.14 \mathrm{mg} / \mathrm{L}$. Those of CHU-MEL and HIA-CHU wastewater were approximately equal but not significant $(\mathrm{p}>0.05)$. On the one hand, the manganese concentrations vary significantly between CNHU-HKM and CHUMEL $(\mathrm{p}<0.05)$ and on the other hand between CNHU-HKM and HIA ( $\mathrm{p}<$ $0.05)$.

There is a significant difference between the average concentration of Zinc at CNHU-HKM and those obtained at CHU-MEL, HIA-CHU and CHUZ-SL with a higher value obtained at CNHU-HKM. The mean concentration of cobalt at

Table 3. Average value of the concentrations in $\mathrm{mg} / \mathrm{L}$ of heavy metals in university hospitals wastewater compared to the WHO and Benin standards.

\begin{tabular}{ccccccc}
\hline Parameters & NE & Min & Max & \multicolumn{2}{c}{ Average Standard deviation Benin's standard } \\
\hline Lead & 30 & 0.006 & 0.49 & 0.21 & 0.12 & 1 \\
Cadmium & 30 & 0.001 & 0.28 & 0.08 & 0.08 & 1 \\
Zinc & 30 & 0.050 & 0.61 & 0.38 & 0.15 & 5 \\
Iron & 30 & 8.32 & 23.88 & 13.89 & 4.53 & - \\
Cupper* & 30 & 1.02 & 2.93 & 1.96 & 0.54 & 2.5 \\
Manganese & 30 & 0.050 & 0.19 & 0.12 & 0.04 & - \\
Chromium & 30 & 0.038 & 0.10 & 0.06 & 0.01 & 2.5 \\
Nickel & 30 & 0.001 & 0.62 & 0.02 & 0.11 & 2.5 \\
Cobalt & 30 & 0.002 & 0.53 & 0.07 & 0.10 & - \\
CHV & 30 & 0.020 & 0.38 & 0.04 & 0.06 & 0.1 \\
\hline
\end{tabular}

$\mathrm{DL}=$ detection limit, ${ }^{*}$ significant, $\mathrm{CHV}$ : Chromium hexa valent. There was no significant difference $(p>0.05)$ between the average levels in each hospital, except for copper $(p<$ 0.05). Moreover, no trace of Arsenic was found in hospital wastewater studied. 
CNHU-HKM $(0.14 \mathrm{mg} / \mathrm{L})$ and CHU-MEL $(0.08 \mathrm{mg} / \mathrm{L})$ were significantly higher than those obtained at HIA-CHU (0.07 mg/L), CHUZ-SL (0.04 mg/L) (Figure 3).

\subsection{Correlations between Variables}

Table 4 presents the correlation analysis between all the variables taken in pairs to determine the potential links between the variables and the possible sources of contamination.

Bivariate analysis of linear correlations provides information on the strength of associations between the parameters studied. Pearson correlation coefficients higher than 0.5 and significant $(\mathrm{p}<0.05)$ are shown in bold at the table level.

\subsubsection{Correlation between Microbiological Parameters}

There were significant and positive correlations between total coliforms and fecal coliforms $(r=0.854)$, total coliforms and fecal streptococcus $(r=0.816)$, and between total coliforms and staphylococcus $(r=0.566)$. A significant and positive correlation was noted between fecal coliforms and fecal streptococcus $(r=$ $0.814)$.

\subsubsection{Correlations between Physico-Chemical Variables}

There were significant and positive correlations between turbidity and suspended solids $(r=0.806)$, with $\mathrm{BOD}_{5}(r=0.789)$ and with $\mathrm{COD}(r=0.795)$. A significant

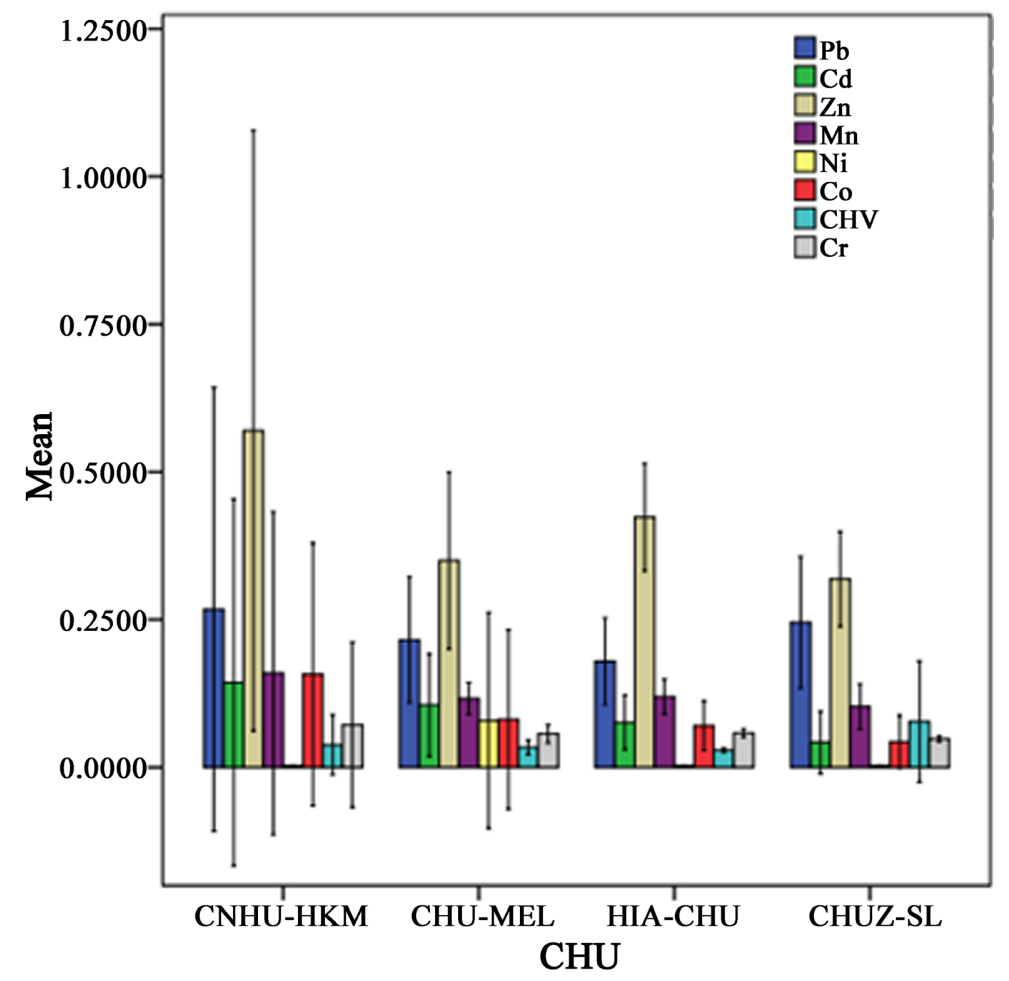

Error bars: $95 \% \mathrm{Cl}$

Pb: Lead, Cd: Cadmium, Zn: Zinc, Mn: Manganese, Ni: Nickel, Co: Colbat, CHV: Chromium Hexa valent, Cr: Chromium total.

Figure 3. Comparison of average concentrations of toxicological parameters. 


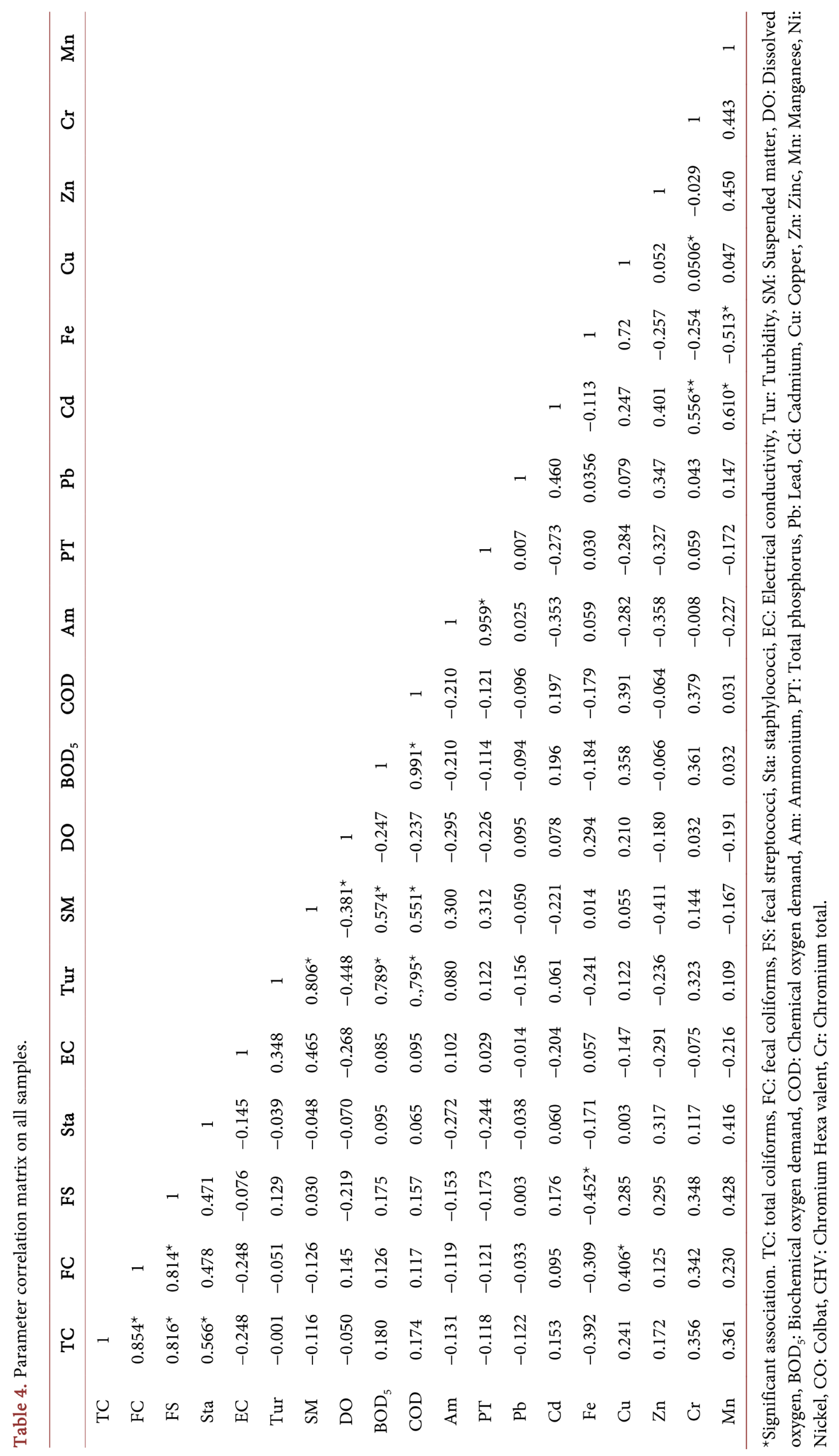


and positive correlation exists between $\mathrm{BOD}_{5}$ and $\mathrm{COD}(r=0.991)$ and between ammonium and phosphorus $(r=0.959)$. In addition, a weak and positive correlation was observed between $\mathrm{SM}$ and $\mathrm{BOD}_{5}(r=0.574)$ and $\mathrm{COD}(r=0.551)$.

\subsubsection{Correlation of Toxicological Parameters}

A significant correlation between cadmium and manganese $(r=0.610)$ was observed. The matrix also reveals a significant negative correlation between iron and manganese $(r=-0.513)$ and a significant positive correlation between copper and chromium $(r=0.506)$.

\section{Discussion}

Microbiological analyses of hospital wastewater have shown the presence of germs such as total coliforms, fecal coliforms, fecal streptococcus, staphylococcus, yeast and Clostridium perfringens. The mean values of fecal coliforms in wastewater from all hospitals were above the WHO standard recommendation for the discharge to the environment. Regarding the physicochemical characteristics, apart from the conductivity which complied with Beninese and WHO standards, all the other parameters show values above the standards for discharging wastewater into the environment. Regarding the heavy metals that are the subject of this study, the average levels observed in the hospital wastewater complied with Beninese standards for discharges of wastewater into the environment.

\subsection{Microbiological Quality}

The microbiological analysis of four university hospital wastewater of Cotonou, revealed the presence of pathogenic germs such as fecal coliforms, staphylococcus, fecal streptococcus and clostridium in the hospital wastewater with the microbial loads were relatively high. Compared to other CHU, CNHU-HKM seems to have high microbial loads for fecal coliforms and staphylococcus, however, with a high range of the confident interval, as shown by the error bars, thus testifying of an inaccuracy of the measurements. This could however be explained by the larger size of the hospital and the partial functioning of its wastewater treatment plant.

Published works in the literature had reported that hospital wastewaters are highly polluted and their discharges without any treatment, can present serious risks to human health and the environment [4] [5] [13]. Our results corroborate those of Adanlokonon et al. in 2018, who reported the presence of coliform bacteria in the wastewater of CHU-MEL [4]. The authors claim that the wastewater contained large amount of fecal coliforms and fecal streptococcus. The presence of fecal contamination indicators such as total coliforms, thermo-tolerant coliforms of the Escherichia coli type, fecal streptococcus and Clostridium spores shows that the wastewater are subject to anthropogenic microbiological pollution.

Releasing this wastewater into the environment without any treatment will increase the potential epidemiological risk [4]. Indeed, the presence of these enterobacteria underpinned the eventuality of the presence of several other patho- 
genic microorganisms [14]. The average total coliforms load found in our study was higher than that reported by Tahiri et al. (2009) and Ameziane et al. (2014) [15] [16]. Fecal coliforms are an indicator of the pollution degree of water and also an indirect indicator of the presence or absence of antibiotics or disinfectants in wastewater [17]. The results of the study of the correlation between the germs showed a good correlation between the different studied parameters (Table 4). The parameters are positively and significantly correlated $(\mathrm{p}<0.05)$ with a correlation coefficient generally greater than 0.5 . Significantly positive correlations were observed between fecal coliforms, fecal streptococcus and total coliforms. This significant and positive correlation is justified by the fact that total coliforms, fecal streptococcus and fecal coliforms are indicators of fecal contamination. The lack of proper treatment of wastewater and the high level of medical activity in these centers could explain the microbiological quality of this wastewater.

\subsection{Physico-Chemical Quality}

The physico-chemical characterization of hospital wastewater includes the evaluation of different parameters. Among these parameters, the most commonly used to assess the presence and the loads of inorganic/organic matter in the effluent are the conductivity, the biochemical oxygen demand, the chemical oxygen demand, the suspended matter and the total nitrogen [18] [19]. The results of the physicochemical characteristics in our study revealed that only the electrical conductivity had average values in accordance with the standards for the discharge of wastewater into the environment. Our results were in agreement with those reported in the literature [20] [21] [22] [23] [24]. It is therefore necessary to properly treat this wastewater before its release into the environment [20]. Ike et al. (2017) in their study carried out in Nigeria reported that hospital wastewater had high values for physicochemical parameters and all values were above Nigerian regulatory standards for the discharge of wastewater into the environment [21]. The most important quality control indicator for hospital wastewater is electrical conductivity, which is used to estimate the overall mineralization and the total of water-soluble salts [11]. The electrical conductivity found in our study varied from $295 \mu \mathrm{S} / \mathrm{cm}$ to $3210 \mu \mathrm{S} / \mathrm{cm}$, with an average of $1300.30 \pm$ $923.459 \mu \mathrm{S} / \mathrm{cm}$. The values that we obtained in the most hospital effluent samples were below the WHO recommendations $(2000 \mu \mathrm{S} / \mathrm{cm})$. Aissi et al. (2013) in their study conducted in the health zones of Calavi and Sô-Ava in the republic of Benin reported electrical conductivity values higher than those obtained in our study [24]. The authors reported in their study electrical conductivity values varying between $3700 \mu \mathrm{S} / \mathrm{cm}$ and $4260 \mu \mathrm{S} / \mathrm{cm}$. Sadek et al. (2012) reported higher values of electrical conductivity $(3140 \mu \mathrm{S} / \mathrm{cm})$ at the hospital in Sidi Kacem [22]. An electrical conductivity between $600-1000 \mu \mathrm{S} / \mathrm{cm}$ is considered to be highly mineralized water [11], the wastewater from our four CHUs are highly mineralized wastewater. The suspended matter represents all of the mineral and organic 
particles contained in the wastewater [11]. In Cote d'Ivoire in 2016, Placide et al. found that the values of nitrate, dissolved oxygen demand, COD, BOD5 and biological parameters of teaching hospital wastewaters did not respect the international (WHO) values recommended for the water to be discharged in the environment [25]. In this study, the average suspended matter content $(96.17 \mathrm{mg} / \mathrm{L})$ obtained also exceeded the limit value of the WHO standards $(20 \mathrm{mg} / \mathrm{L})$ for discharges of wastewater [12]. These results explain the low level of dissolved oxygen in this sense that the degradation of suspended matter consumes a significant amount of the oxygen available in the medium. Hospital wastewaters have high levels of nutritive salts, including nitrogenous compounds. The presence of ammonia in large quantities is indicative of anthropogenic contamination probably due to the transformation of the speed of urea into ammonia [26].

$\mathrm{BOD}_{5}$ is a parameter used to assess the fraction of biodegradable organic matter. The average value of $\mathrm{BOD}_{5}$ and $\mathrm{COD}$ recorded in our study were higher than the standard accepted in Benin. However, the hospital wastewaters in our study are biodegradable as the $\mathrm{COD} / \mathrm{BOD}_{5}$ ratio (1.84) is less than 3 [11]. Therefore, there is the possibility to expect further degradation of organic matter via biological oxidation treatment. Higher average concentrations of COD $(820.20 \mathrm{mg} / \mathrm{L})$ were reported in the wastewater of $\mathrm{Al}$ Ghassani hospital in 2009. As regards $\mathrm{BOD}_{5}$, higher average concentrations $(1881.1 \mathrm{mg} / \mathrm{L})$ have also been recorded [27].

Statistical analysis showed that there is a strong positive correlation between turbidity and suspended solids $(r=0.806)$. The turbidity of water is due to the presence of particles in suspension, in particular colloidal. Turbidity, $\mathrm{BOD}_{5}$ and COD are indicators of the organic pollution of wastewater, which justifies the existence of positive correlation between these parameters. The strong positive correlation observed between $\mathrm{BOD}_{5}$ and $\mathrm{COD}(\mathrm{r}=0.991)$ is justified by the fact that the two parameters reflect the significant contribution of organic matter present in hospital wastewater. Ammonium and phosphorus are essential nutrients for plants and are eutrophying substances, which explain the observation of the strong positive correlation between ammonium and total phosphorus $(r=0.959)$. The phenomenon of eutrophication may be due to the high concentrations of nitrates and phosphates.

\subsection{Toxicological Quality}

The average levels of metals in the wastewater complied with Benin's standards for discharges of wastewater into the environment. It was reported that the main heavy metals present in hospital wastewater are gadolinium, mercury and platinum $(\mathrm{Pt})$. Other heavy metals such as Cadmium, Copper, Iron, Nickel, Lead and Zinc are generally present [28]. The presence of heavy metals in hospital wastewater is linked to the presence of iodinated contrast agents used for radiography, certain drugs which may contain organ ohalogenated elements, the use of disinfectants, detergents and chlorinated solvents, as well than other substances from laboratories. However, although these concentrations are low, the continual in- 
troduction of heavy metals into the aquatic environment is potential the source of harmful effects on marine organisms because of their bioaccumulation and biomagnification properties [29] [30]. Cadmium and lead are cumulative toxics, capable of accumulating in aquatic food products and causing a number of disturbances in humans [31] [32]. Cadmium is a transition metal known to be carcinogenic, mutagenic and cytotoxic. In addition, various studies have highlighted the toxic potential of these metals, because they exert a systemic toxic action, cause damage to various organs even at low doses and are carcinogenic to humans [33] [34]. In addition, the mixture of various pharmaceutical products, metabolites, detergents, antiseptics, metals, contrast agents, etc., all present in hospital wastewater, can generate interactions which generally potentiate the toxicity of its chemical components.

\section{Conclusion}

The present study has permitted to give an insight on various microbiological, physicochemical and metal contaminants in the wastewater from university hospitals. Despite the fact that some of the measurements lack of precision, this can be concluded that the studied hospital wastewater is of very bad quality. These hospital wastewaters represent a great risk for the environment as well as for human well-being and therefore require adequate treatment for the elimination of the greatest possible number of contaminants. Studies like this are important in revealing the health and environmental risks associated with the discharge of untreated wastewater. The importance of identifying the problem of hospital liquid discharges is today an emergency measure on an international scale and it is now time for it to be among the national strategic concerns in Benin. In the light of the results of this study, we hope to have contributed to a real awareness of the competent authorities on the need to develop hospital wastewater treatment plants at the level of healthcare facilities.

\section{Acknowledgements}

The authors thank the University of Abomey-Calavi through the Third Phase Competitive Research Fund Program for funding this doctoral thesis.

\section{Funding}

This work was funded by the University of Abomey-Calavi through the Third Phase Competitive Research Fund Program (No. 632-2018/UAC/SG/AC/SAF/ VR-RU/SPRSP/SA).

\section{Authors' Contribution}

GS and DM are the principal investigators. JT is a PhD Student. He participated in the planning and carrying out of the study. GS, CD, and DM designed the study method; GS, CD, AY, FS and DM participated in the planning of the study and contributed to the writing process. ES, FG and JWH participated in the data 
analysis and contributed to the writing process. All authors have read and approved the final manuscript.

\section{Conflicts of Interest}

All authors do not declare any conflict of interest.

\section{References}

[1] Ministère des Affaires sociales et de la Santé (2016) Guide pratique-Pour une bonne gestion des déchets produits par les établissements de santé et médico-sociauxDéchets issus de médicaments-Déchets liquides. Rédaction Direction générale de la santé (DGS) Conception Délégation à l'information et à la communication (Dicom)

[2] Carvalho, I.T. and Santos, L. (2016) Antibiotics in the Aquatic Environments: A Review of the European Scenario. Environment International, 94, 736-757. https://doi.org/10.1016/j.envint.2016.06.025

[3] Prichard, E. and Granek, E.F. (2016) Effects of Pharmaceuticals and Personal Care Products on Marine Organisms: From Single-Species Studies to an Ecosystem-Based Approach. Environmental Science and Pollution Research, 23, 22365-22384. https://doi.org/10.1007/s11356-016-7282-0

[4] Adanlokonon, E.A., Kanhounnon, W.G., Chabi, B.C., Adjahouinou, D.C, Koumolou, L., Bonou, B., Fiogbe, E.D. and Edorh, P.A. (2018) Physicochemical and Microbio-logical Characterization of Effluents from the "Centre Hospitalier Universitaire de la Mère et de l'Enfant Lagune (CHU-MEL)" Discharged in the Cotonou Lagoon in Benin. International Journal of Biological and Chemical Sciences, 12, 1955-1964. https://doi.org/10.4314/ijbcs.v12i4.34

[5] Yessoufou, A. (2017). Etude diagnostique de la pollution métallique, produits pharmaceutiques et de soins personnels (ppsp) en milieux aquatiques: cas des sédiments du lac nokoué, du déversoir d'eaux usées d'hôpital et des boues de la station d'épuration sibeau au bénin. Thèse de doctorat en chimie minérale, Université d'abomey-calavi, Benin.

[6] Roig, B. (2010) Pharmaceutical in the Environment: Current Knowledge and Need Assessment to Reduce Presence and Impact. Vol. 9, IWA Publishing, London, 198. https://doi.org/10.2166/9781780401430

[7] Roig, B. and D'Acco, V. (2016) Distribution of Environmental Residues in the Environment. In: Hester, R.E. and Harrison, R.M., Eds., Pharmaceuticals in the Environment, Royal of Society Chemistry, London, 34-69. https://doi.org/10.1039/9781782622345-00034

[8] Carraro, E., Si, B., Bertino, C., Lorenzi, E., Sa, B. and Gilli, G. (2016) Hospital Effluents Management: Chemical, Physical, Microbiological Risks and Legislation in Different Countries. Journal of Environmental Management, 168, 185-199. https://doi.org/10.1016/j.jenvman.2015.11.021

[9] World Health Organization (1999) Safe Management of Wastes from Health-Care Activities. World Health Organization, Geneva.

[10] République du Bénin (2001) Décret n²001-109 du 4 avril 2001 fixant les normes de qualité des eaux résiduaires en république du Bénin. Journal Officiel de la République du Bénin, 1-27. https://sgg.gouv.bj/doc/decret-2001-109/

[11] El-Ogri, F., Ouazzani, N., Boraâm, F. and Mandi, L. (2016) A Survey of Wastewaters Generated by a Hospital in Marrakech City and Their Characterization. Desalination 
and Water Treatment, 57, 17061-17074.

[12] Rodier, J., Legube, B., Merlet, N., et al. (2009). L'analyse de l'eau. 9th Edition, Dunod, Paris.

[13] World Health Organization (2014) Safe Management of Wastes from Health-Care Activities. 2nd Edition, Word Health Organization, Geneva.

[14] Akplogan, S., Johnson, R.C., Dégbey, C., Boko, M., Makoutode, M. and Fayomi, B. (2014) Assessment of the Biomedical Wastewater Treatment Station of the National University Hospital of Cotonou Benin, West Africa. Journal of Biodiversity and Environmental Sciences, 5, 157-163.

[15] Ajit, K.P., Bhaskar, C.A. and Anil, M. (2009) Occurrence and Distribution of Bacterial Pathogens in Coastal Indicators and Waters of Orissa. Indian Journal of Geo-Marine Sciences, 38, 474-480.

[16] Tahiri, E., Benaabidate, L., Nejjari, C. and Fikri, B.K. (2009) Caractérisation des effluents liquides de l'hôpital Al Ghassani, CHU Hassan II de Fès, Maroc. Les effluents liquides des établissements de santé: état des lieux et perspectives de gestion. Chambéry.

[17] Ameziane, N. and Benaabidate, L. (2014) Caractérisation microbiologique des effluents de l'hôpital Mohamed V de Meknès et étude de leur impact sur l'environnement. Nature \& Technologie, 10, 31-38.

[18] Emmanuel, E. (2004) Evaluation des risques sanitaires et écotoxicologiques liés aux effluents hospitaliers. Thèse de doctorat, Institut national des sciences appliquées de Lyon, Lyon, 245-246.

[19] Verlicchi, P., Al Aukidy, M., Galletti, A., Petrovic, M. and Barcelo, D. (2012) Hospital Effluent: Investigation of the Concentrations and Distribution of Pharmaceuticals and Environmental Risk Assessment. Science of the Total Environment, 430, 109-118. https://doi.org/10.1016/j.scitotenv.2012.04.055

[20] Al Aukidy, M., Verlicchi, P. and Voulvoulis, N. (2014) A Framework for the Assessment of the Environmental Risk Posed by Pharmaceuticals Originating from Hoapital Effluents. Science of the Total Environment, 493, 54-64.

https://doi.org/10.1016/j.scitotenv.2014.05.128

[21] Berrada, S., Squalli, F.Z., Squalli, H.T., Hannin, M., El Oualti, A. and Lalami, A. (2014) Recyclage des effluents du service d'hémodialyse de l'hôpital Al Ghassani de la ville de Fès: Caractérisation avant et après traitement. Journal of Materials and Environmental Science, 5, 2265-2277.

[22] Ike, C.C. and Akwari, D.K. (2017). Microbiological and Physicochemical Quality of Hospital "X" Effluent in Aba, Abia State, Nigeria. IJRDO Journal of Applied Science, 3, 26-37.

[23] Sadek, S., Elkharrim, K., Khadmaoui, A., Guissouss, M., Benelharkati, F., Elmarkhi, M. and Driss, B. (2012) Caractérisation physico-chimique des eaux usées de l'hôpital provincial de Sidi Kacem (Maroc). Science Library, 4, Article ID: 120713.

[24] Bouzid, J., Chahlaoui, A., Zaid, A., My Mehdi, R. and Bouhlou, L. (2013) Etude bactériologique et physicochimique des effluents liquides de l'hôpital Mohamed V de Meknès. Science Library, 5, Article ID: 130803.

[25] Placide, S.S., Mohamed, B., Hélène, L.E.M., Auguste, A.F.T., Quand-Meme, G.C., Sanogo, I. and Ouattara, L. (2016) Assessment of the Physicochemical and Microbiological Parameters of a Teaching Hospital's Wastewaters in Abidjan in Côte d'Ivoire. Journal of Water Resource and Protection, 8, 1251-1265. https://doi.org/10.4236/jwarp.2016.813096

[26] Aissi, A., Edorh, P.A., Degbey, C., Guedenon, P., Segbo, J., Hounkpatin, A.S.Y., Boko, 
M. and Loko, F. (2013) Assessment of Risk Connected to the Management of Effluents from Abomey-Calavi and So-Ava Laboratories. British Journal of Applied Science \& Technology, 3, 307-319. https://doi.org/10.9734/BJAST/2014/2296

[27] EL Mountassir, R., Bennani, B., Merzouki, H., Benjelloun, T.G., Boumchita, S., Benjelloun, Y. and Lahrichi, A. (2017) Characterization of the Chemical and Bacteriological Risks of the Effluents from Some Services of the Hassan II Hospital Center in Fez. Journal of Materials and Environmental Science, 8, 2288-2295.

[28] El Mehdi, T., Lahcen, B., Chakib, N. and Kawtar, F.B. (2009) Caractérisation des effluents liquides de l'hôpital Al Ghassani, CHU Hassan II de Fès, Maroc. Les effluents liquides des établissements de santé: Etat des lieux et perspectives de gestion. Revue Techniques Hospitalières, 714, 47-50.

[29] Verlicchi, P., Galletti, A., Petrovic, M. and Barcelo, D. (2010) Hospital Effluents as a Source of Emerging Pollutants: An Overview of Micropollutants and Sustainable Treatment Options. Journal of Hydrology, 389, 416-428.

https://doi.org/10.1016/j.jhydrol.2010.06.005

[30] Lim, S.R. and Schoenung, J.M. (2010) Human Health and Ecological Toxicity Potentials Due to Heavy Metal Content in Waste Electronic Devices with Flat Panel Displays. Journal of Hazardous Materials, 177, 251-259. https://doi.org/10.1016/j.jhazmat.2009.12.025

[31] Baby, J., Raj, J.S., Etsankarganesh, P., Jeevitha, M.V., Ajisha, S.U. and Rajan, S.S. (2010) Toxic Effect of Heavy Metals on Aquatic Environment. International Journal of Biological and Chemical Sciences, 4, 939-952. https://doi.org/10.4314/ijbcs.v4i4.62976

[32] Oliveira, H., Lopes, T., Almeida, T., Pereira, M.L. and Santos, C. (2012) CadmiumInduced Genetic Instability in Mice Testis. Human \& Experimental Toxicology, 31, 1228-1236. https://doi.org/10.1177/0960327112445937

[33] Prozialeck, W.C. and Edwards, J.R. (2012) Mechanisms of Cadmium-Induced Proximal Tubule Injury: New Insights with Implications for Biomonitoring and Therapeutic Interventions. Journal of Pharmacology and Experimental Therapeutics, 343, 2-12. https://doi.org/10.1124/jpet.110.166769

[34] Tchounwou, P.B., Yedjou, C.G., Patlolla, A.K. and Sutton, D.J. (2012) Molecular, Clinical and Environmental Toxicology. Vol. 101, Springer, Basel, 1-30. 